\title{
Purification and Characterization of an Abnormal Factor IX (Christmas Factor) Molecule
}

\author{
FACTOR IX CHAPEL HILL
}

\author{
Kuo-San Chung, Dean A. Madar, Jonathan C. Goldsmith, Henry S. Kingdon, \\ and HAROLd R. Roberts, Departments of Medicine, Pathology, Biochemistry, \\ and Chemistry, The University of North Carolina, Chapel Hill, \\ North Carolina 27514
}

\begin{abstract}
A B S T RACT Human Factor IX (Christmas factor) was isolated from the plasma of a patient with mild hemophilia B. The patient's plasma contained 5\% Factor IX clotting activity but $100 \%$ Factor IX antigenic activity as determined by immunological assays, which included inhibitor neutralization and a radioimmunoassay for Factor IX. This abnormal Factor IX is called Factor IX Chapel Hill (Factor IX $\mathrm{X}_{\mathbf{C H}}$ ). Both normal Factor IX and Factor $\mathrm{IX}_{\mathrm{CH}}$ have tyrosine as the $\mathbf{N H}_{2}$ terminal amino acid. The two proteins have a similar molecular weight, a similar amino acid analysis, the same number of gamma-carboxyglutamic acid residues (10 $\gamma$-carboxyglutamic acid residues), and a similar carbohydrate content. Both exist as a single-chain glycoprotein in plasma. The major difference between normal Factor IX and Factor $\mathrm{IX}_{\mathrm{CH}}$ is that the latter exhibits delayed activation to Factor IXa in the presence of Factor XIa and $\mathrm{Ca}^{2+}$. Thus, Factor IX $\mathrm{IXH}_{\mathrm{CH}}$ differs from other previously described abnormal Factor IX molecules.
\end{abstract}

\section{INTRODUCTION}

Factor IX (plasma thromboplastin component, Christmas factor) is a clotting factor which participates in the middle phase of intrinsic blood coagulation. Diminished activity of this factor results in hemophilia B. Factor IX is a glycoprotein that has been isolated from both the human and bovine species and many of the characteristics of the normal factor have been published (1-8). In the circulation, Factor

An abstract of this work appeared in 1976. Blood. 48: 974. (Abstr.)

Dr. Goldsmith was supported by a National Hemophilia Foundation Fellowship.

Received for publication 3 February 1978 and in revised form 13 July 1978.
IX exists as a single-chain zymogen which is converted to an active serine protease in the presence of Factor XIa (plasma thromboplastin antecedent) and $\mathrm{Ca}^{2+}$ ions (9). During activation, the Factor IX zymogen undergoes proteolysis in a two-stage reaction that results in a two-chain molecule composed of a light and heavy chain linked by disulfide bonds. The first step in the proteolysis is the cleavage of a specific argininealanine peptide bond which results in an inactive intermediate product. The second cleavage splits an arginine-valine peptide bond with the release of a carbohydrate-rich activation peptide and an active Factor IX enzyme $(10,11)$. The active site serine resides on the heavy chain (11).

Activated Factor IX (Factor IXa), in the presence of phospholipids, thrombin-modified Factor VIII, and calcium ions, converts Factor X to Factor Xa (2). However, the precise molecular interactions of Factor IXa with calcium, phospholipid, Factor VIII, and Factor $\mathrm{X}$ are not completely understood. Elucidation of the nature of the defect in abnormal Factor IX molecules found in some patients with hemophilia B (Christmas disease) may provide insights into function of normal Factor IX in hemostasis and its interaction with other clotting factors. Roberts et al. (12), and other investigators (13-19) have demonstrated that some patients with hemophilia B possess an abnormal Factor IX molecule which has low to undetectable clotting activity, but which is present in relatively normal amounts when measured by immunological techniques $(12,20-22)$. Because they contain cross-reacting material (CRM) ${ }^{1}$ to specific homologous and heterologous

${ }^{1}$ Abbreviations used in this paper: CRM, cross-reacting material; $\mathrm{CRM}^{+}, \mathrm{CRM}$ positive variants; $\mathrm{CRM}^{-}, \mathrm{CRM}$ negative variants; CRM $^{\mathrm{R}}, \mathbf{C R M}$ reduced variants; Factor $\mathrm{IX}_{\mathrm{CH}}$, Factor IX Chapel Hill; SDS, sodium dodecyl sulfate. 
anti-Factor IX antibodies, these patients have been termed $\mathrm{CRM}^{+}$(CRM positive variants). They can be distinguished from other hemophilia $B$ patients who have reduced, but not absent, levels of both Factor IX antigen and Factor IX clotting activity $\left(\mathrm{CRM}^{\mathrm{R}}\right.$; CRM reduced variants). The $\mathrm{CRM}^{+}$patients can also be distinguished from those hemophilia $B$ patients in whom Factor IX antigen and Factor IX clotting activity are absent or undetectable $\left(\mathrm{CRM}^{-}\right.$; $\mathrm{CRM}$ negative variants) (22).

The purpose of this paper is to describe the isolation and characteristics of an abnormal Factor IX molecule from a mildly affected $\mathrm{CRM}^{+}$hemophilia B patient. This abnormal Factor IX has been named Factor IX Chapel Hill (Factor IX $\mathrm{X}_{\mathrm{CH}}$ ) (23). Factor $\mathbf{I X} \mathbf{X}_{\mathrm{CH}}$ is compared with purified normal human Factor IX in terms of its molecular weight, $\mathrm{NH}_{2}$-terminal amino acid, content of $\gamma$-carboxyglutamic acid residues, carbohydrate content, and activation by Factor XIa and $\mathrm{Ca}^{2+}$. The major abnormality in Factor IX $_{\mathrm{CH}}$ appears to be defective activation by Factor XIa and $\mathrm{Ca}^{2+}$, although abnormalities in interactions with other clotting factors cannot be excluded.

\section{METHODS}

Materials. The patient with Factor $\mathrm{IX}_{\mathrm{CH}}$ is a 30 -yr-old white male who has been followed at the University of North Carolina Hospital for 16 yr. He has a mild bleeding tendency and a Factor IX level of 5\% of normal when tested in one-stage clotting assays. With a specific antibody to Factor IX, however, the patient was found to have $100 \%$ of Factor IX when measured by an antibody neutralization test and a radioimmunoassay for Factor IX (vide infra). All other clotting factors were normal. Plasma for purification of Factor $\mathrm{IX}_{\mathrm{CH}}$ was obtained from this patient who was previously shown to be $\mathrm{CRM}^{+}(24)$. The patient was plasmapheresed every $2 \mathrm{wk}$ to $1 \mathrm{mo}$, after informed consent, until sufficient plasma was obtained for the studies outlined below. The blood was handled in a manner similar to that for normal blood as described below. The resultant plasma was stored at $-70^{\circ} \mathrm{C}$ and thawed at $37^{\circ} \mathrm{C}$ just before use. Normal, pooled human plasma was obtained from the Blood Bank of the North Carolina Memorial Hospital, Chapel Hill, N. C. Human blood was collected in plastic bags that contained standard citrate phosphate dextrose anticoagulant and centrifuged at $3,000 \mathrm{~g}$ for $30 \mathrm{~min}$ at $4^{\circ} \mathrm{C}$ to render the plasma platelet poor and free of erythrocytes. The plasma was then recentrifuged under the same conditions. Plasmas used for the purification of normal Factor IX were either fresh or stored for $<2$ mo at $-70^{\circ} \mathrm{C}$.

Alumina C- $\gamma$ gel was purchased from Calbiochem, San Diego, Calif. Benzamidine hydrochloride and cyanogen bromide were purchased from Eastman Organic Chemicals, Div. Eastman Kodak Co., Rochester, N. Y. Heparin sodium salt, bovine serum albumin, dithioerythritol, dansyl chloride, dansyl amino acids, galactose, mannose, glucose, fucose, Nacetylneuraminic acid, and amino sugars were obtained from Sigma Chemical Co., St. Louis, Mo. DEAE-cellulose was Whatman DE-52 (Whatman Chemicals, Div. W \& R Balston, Maidstone, Kent, England). DEAE-Sephadex (A-50), Sephadex G-150, Ribonuclease A, chymotrypsinogen A, and ovalbumin were purchased from Pharmacia Fine Chemicals, Uppsala,
Sweden. Bovine brain cephalin (Thrombofax) was purchased from Ortho Pharmaceuticals Corporation, Raritan, N. J. Thromboplastin reagent (Simplastin) was purchased from General Diagnostics, Warner Lambert Company, Morris Plains, N. J. Agarose (Bio-Gel A-15 m, 100-200 mesh), Aminex A-4 Resin, $\beta$-mercaptoethanol, and materials used in gel electrophoresis were obtained from Bio-Rad Laboratories, Richmond, Calif. Celite 545 was purchased from Johns-Manville, Denver, Colo. All other chemicals were of reagent grade or better.

Protein concentrations. The Lowry method (25), with bovine serum albumin as a standard, was used for the estimation of protein concentration for the early stages of purification of Factor IX. Protein concentration on the final product was estimated by optical adsorption at $280 \mathrm{~nm}$ with experimentally determined extinction coefficients (vide infra).

Coagulation assays. I U of Factor VII, VIII, IX, or X clotting activity was defined as that amount in $1 \mathrm{ml}$ of normal, pooled human plasma. A one-stage assay, based on the partial thromboplastin time, was used for the measurement of Factors VIII and IX $(26,27)$. Factors X and VII were measured by a one-stage assay based on the prothrombin time (28). Prothrombin was assayed with a two-stage method (29). Factor XI was assayed with artificially depleted human plasma (30) as well as plasma congenitally deficient in Factor XI (31). Factor IX immunological activity was assayed by an inhibitor-neutralization technique $(12,21)$. Factor IX was also measured by a radioimmunoassay with purified normal human Factor IX and a human anti-Factor IX antibody (32).

Preparation of heparin-agarose. Heparin-agarose was prepared by a modification of the method described by Porath (33) and Cuatrecasas (34).

Electrophoresis. Disc gel electrophoresis was performed in $0.2 \mathrm{M} \mathrm{N}, \mathrm{N}$-bis[2-hydroxyethyl]glycine-imidazole buffer at $\mathrm{pH} 7.8$ for nondenatured protein and $0.025 \mathrm{M}$ Tris-glycine buffer at $\mathrm{pH} 8.3$ for sodium dodecyl sulphate-treated protein (35). 7.5 and $10 \%$ polyacrylamide gels were used for analytical separation of the proteins with $3 \%$ polyacrylamide as the stacking gel. $\beta$-Mercaptoethanol and dithioerythritol were used as reducing agents. Immuno-electrophoresis was performed on $1 \%$ agarose gel in $0.075 \mathrm{M}$ Tris-barbital buffer at $\mathrm{pH} 8.6$ which contained $2 \mathrm{mM}$ of calcium lactate.

Purification of Factor $I X_{\mathrm{CH}} .60 \mathrm{ml}$ of cold alumina gel was stirred into $600 \mathrm{ml}$ of cold platelet-poor plasma, obtained from the patient with Factor $\mathrm{IX}_{\mathrm{CH}}$, for $5 \mathrm{~min}$ at $25^{\circ} \mathrm{C}$. The plasma was centrifuged and the supernate decanted. The adsorbate was washed twice with cold, normal saline and then eluted with $30 \mathrm{ml} 0.3 \mathrm{M}\left(\mathrm{NH}_{4}\right)_{2} \mathrm{HPO}_{4}$ buffer at $\mathrm{pH} 8.5$. The elution was repeated at least once. Pooled eluate was dialyzed against 4 liters of $0.01 \mathrm{M}$ sodium phosphate buffer at $\mathrm{pH}$ 7.0. The dialysate was then applied to a DEAE-cellulose (DE-52, Whatman Chemicals $)$ column $(2.5 \times 25 \mathrm{~cm})$ which was washed extensively with sodium phosphate buffer containing 0.13 $\mathrm{NaCl}$ until the OD $(280 \mathrm{~nm})$ of the effluent was $<0.01$. The column was eluted with a linear gradient of $\mathrm{NaCl}$ (from $0.13 \mathrm{M}$ to $0.30 \mathrm{M}$ ) with an automatic level sensor. Factor $\mathrm{IX}_{\mathrm{CH}^{-}}$-rich fractions were pooled and dialyzed against 4 liters of $0.05 \mathrm{M}$ sodium citrate at $\mathrm{pH}$ 7.0. The dialysate was applied to a DEAESephadex column $(2.3 \times 12 \mathrm{~cm})$ (Pharmacia Fine Chemicals) which was washed with $0.08 \mathrm{M}$ sodium citrate $(\mathrm{pH} 7.0)$ until the OD $(280 \mathrm{~nm})$ was $<0.01$. A linear gradient of sodium citrate from 0.08 to $0.30 \mathrm{M}(\mathrm{pH} 7.0)$ was then used to elute

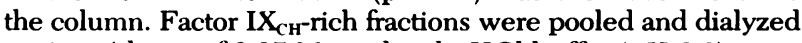
against 4 liters of $0.05 \mathrm{M}$ imidazole- $\mathrm{HCl}$ buffer $(\mathrm{pH} 6.0$ ) overnight, and the dialysate was brought to $2.5 \mathrm{mM} \mathrm{CaCl}$ concentration with a $1-\mathrm{M} \mathrm{CaCl}_{2}$ stock solution. A heparin-agarose column $(1.1 \times 4.5 \mathrm{~cm})$ was used for the last step of purification. After the Factor IX solution was applied, the column was washed with $250 \mathrm{ml}$ of imidazole-HCl buffer which contained 
$0.25 \mathrm{M} \mathrm{NaCl}$ and $2.5 \mathrm{mM} \mathrm{CaCl}$. Factor IX was eluted with $0.4 \mathrm{M} \mathrm{NaCl}$ and $2.5 \mathrm{mM} \mathrm{CaCl}_{2}$ in the same buffer. The procedures were carried out at $4^{\circ} \mathrm{C}$ except when stated otherwise. All solutions used in the purification procedure contained $1 \mathrm{mM}$ benzamidine hydrochloride. Purification was monitored by a two-stage Factor IX neutralization assay as well as clotting assays for Factors II, VII, VIII, IX, and X.

Purification of normal human Factor IX. Purification of normal Factor IX was similar to that described for Factor $\mathrm{IX}_{\mathrm{CH}}$.

Preparation of Factor XIa. $10 \mathrm{ml}$ of normal, pooled plasma was adsorbed twice with alumina C- $\gamma$ gel for $30 \mathrm{~min}$ at $25^{\circ} \mathrm{C}$. After centrifugation, the supernatant plasma was incubated with $200 \mathrm{mg}$ of prewashed Celite 545 (Johns-Manville) in a plastic tube at $37^{\circ} \mathrm{C}$ for $10 \mathrm{~min}$. The tube was inverted every 1-2 min. The Celite suspension was collected by centrifugation and then washed 3 times with $10 \mathrm{ml}$ of distilled water. Factor XIa was eluted from the Celite with $10 \mathrm{ml}$ of $10 \%$ saline, and dialyzed against buffered citrated saline (pH 7.2). Factor XIa was also purified by the method of Lundblad and Kingdon (36) and used for the activation of purified Factor IX.

Molecular weight. The molecular weight was estimated by the electrophoretic mobility method with sodium dodecyl sulfate (SDS) disc gel electrophoresis as described above (35).

Inhibitor neutralization assay and radioimmunoassay for Factor IX. The inhibitor neutralization assay was performed according to the method of Roberts et al. (12). A radioimmunoassay was carried out according to the method described by Reisner et al. (32).

Activation of Factor IX by Factor XIa and $\mathrm{Ca}^{2+} . \quad 3 \mathrm{mg}$ of purified, normal human Factor IX were incubated with 100 $\mu$ g of partially purified Factor XIa at $37^{\circ} \mathrm{C}$ in $0.05 \mathrm{M}$ imidazole buffer (pH 6.0) in a final volume of $3 \mathrm{ml}$ which contained $5 \mathrm{mM}$ of $\mathrm{CaCl}_{2}$. At selected time intervals an aliquot of the incubation mixture was added to platelet-poor, unactivated Factor IX-deficient substrate plasma obtained from a severely affected $\mathrm{CRM}^{-}$hemophilia B patient. A nonactivated, partial thromboplastin time and a Factor IX assay were performed on the final mixture. At the same time intervals, aliquots from the first incubation mixture were evaluated on SDS gel electrophoresis to determine the time of appearance of lower molecular weight components. Factor $\mathrm{IX}_{\mathrm{CH}}$ was also activated in the same manner, and monitored in a similar fashion. Appropriate controls were run by substituting imidazole buffer for Factor XIa, Factor IX, and $\mathrm{Ca}^{2+}$ in the incubation mixture.

$\mathrm{NH}_{2}$-terminal amino acid analysis. The $\mathrm{NH}_{2}$-terminal amino acid was determined by Edman degradation (37) with a Beckman model 890-C Sequencer (Beckman Instruments, Inc., Fullerton, Calif.). Phenyl isothiocyanate was coupled to the free amino terminal group of the protein by incubation at $55^{\circ} \mathrm{C}$ for $15 \mathrm{~min}$. Anhydrous heptafluorobutyric acid was used to release the phenyl isothiocyanate derivative of the $\mathrm{NH}_{2}$-terminal amino acid which was identified by gas chromatography. The $\mathrm{NH}_{2}$-terminal amino acid was also determined by thin layer chromatography with dansyl chloride (38).

Amino acid composition of human Factor IX. Amino acid analysis was performed by the method of Spackman et al. (39). Samples in $6 \mathrm{~N} \mathrm{HCl}$ were sealed in Pyrex (Corning Glass Works, Corning, N. Y.) tubes (Research \& Development Products, Berkeley, Calif.) at reduced pressure and hydrolyzed at $110^{\circ} \mathrm{C}$ for 24 and $72 \mathrm{~h}$. $\gamma$-Carboxyglutamic acid was quantitated from alkaline hydrolysates of protein with a modification of the method of Hauschka et al. (40). $1 \mathrm{mg}$ of each of these samples was dissolved in $2 \mathrm{ml}$ of $2 \mathrm{~N} \mathrm{KOH}$ and sealed at reduced pressure in glass tubes lined with polypropylene. $\mathrm{Hydrolysis}$ was carried out at $110^{\circ} \mathrm{C}$ for $24 \mathrm{~h}$. After alkaline hydrolysis, samples were brought to $\mathrm{pH} 7.0$ by drop-wise addition of $35 \% \mathrm{HClO}_{4}$. The solutions were evaporated and the amino acids were eluted from the precipitate cake with aliquots of $0.2 \mathrm{~N}$ sodium citrate buffer, $\mathrm{pH} 2.2$. Amino acid analyses were performed on either a modified Phoenix model VG6000-B (Phoenix Precision Instrument, Div. Virtis Co., Inc., Gardiner, N. Y.) or a Beckman model 116 analyzer (Beckman Instruments, Inc.). The determination of cystine as cysteic acid was performed after Moore (41) with bovine prothrombin as a standard to determine the yield of the reaction. The relative amount of tryptophan to tyrosine in Factor IX was determined by a spectrophotometric method (42) in $0.1 \mathrm{~N}$ $\mathrm{NaOH}$ with a Cary 118 spectrophotometer (Cary Instruments, Fairfield, N. J.). Tryptophan residues per molecule of Factor IX were calculated from the tyrosine residues obtained in the acid hydrolysis.

Carbohydrate composition. Neutral sugars were determined by quantitative gas liquid chromatography (43) after being released from the protein by hydrolysis in $2 \mathrm{~N} \mathrm{H}_{2} \mathrm{SO}_{4}$ at $100^{\circ} \mathrm{C}$ for $5 \mathrm{~h}$ and converted to alditol acetates (44). A colorimetric method with the phenolsulfuric acid reaction and a 1:1 mixture of galactose and mannose as standard was also employed to confirm the result of total hexoses (45). Total hexosamine was determined according to Gardell (46). Sialic acid was assayed with 2-thiobarbituric acid (47).

Extinction coefficient. Purified normal Factor IX and Factor $\mathrm{IX}_{\mathrm{CH}}$ were rendered salt-free and lyophilized. The lyophilized proteins were then dissolved in $0.05 \mathrm{M}$ imidazole$\mathrm{HCl}$ buffer ( $\mathrm{pH} \mathrm{6.0)}$ and the optical absorption at $280 \mathrm{~nm}$ was measured and extinction coefficients were calculated.

\section{RESULTS}

Summaries of the purification results of Factor $\mathrm{IX}_{\mathrm{CH}}$ and normal Factor IX are shown in Tables I and II, respectively. Both normal Factor IX and Factor $\mathrm{IX}_{\mathrm{CH}}$ were purified from 17,000 - to 18,000 -fold with a yield ranging from 47 to $53 \%$.

When the final products were electrophoresed on SDS gels only one band was seen for normal Factor IX and Factor IX $\mathrm{X}_{\mathrm{CH}}$ as shown in Fig. 1. The apparent molecular weights according to this technique were 70,000 for both the normal product and Factor $\mathrm{IX}_{\mathrm{CH}}$. When both normal Factor IX and IX $\mathrm{X}_{\mathrm{CH}}$ were run in SDS gels in the presence of $\beta$-mercaptoethanol or dithioerythritol, only one band was seen, which in-

TABLE I

Purification of Factor $I X_{C H}$

\begin{tabular}{lrcccc}
\hline \multicolumn{1}{c}{ Stage } & $\begin{array}{c}\text { Vol- } \\
\text { ume }\end{array}$ & $\begin{array}{c}\text { Total } \\
\text { protein }\end{array}$ & $\begin{array}{c}\text { Clotting } \\
\text { activity }\end{array}$ & Yield & Purification \\
\hline & $m l$ & $m g$ & $U$ & $\%$ & - fold \\
Plasma & 600 & $3.1 \times 10^{4}$ & 28.2 & 100 & 1 \\
$\begin{array}{l}\text { Al }(\mathrm{OH})_{3} \\
\text { DE-52 }\end{array}$ & 60 & 155 & 26.8 & 95 & 190 \\
$\begin{array}{l}\text { DEAE- } \\
\begin{array}{c}\text { Sephadex } \\
\text { Heparin- }\end{array}\end{array}$ & 60 & 2.65 & 17.7 & 63 & 7,340 \\
agarose & 35 & 0.96 & 16.3 & 58 & 18,700 \\
& & 5.89 & 19.5 & 69 & 3,640 \\
\hline
\end{tabular}

* Antigenic determination in parentheses. 
TABLE II

Purification of Normal Human Factor IX

\begin{tabular}{lrcccr}
\hline \multicolumn{1}{c}{ Stage } & $\begin{array}{c}\text { Vol- } \\
\text { ume }\end{array}$ & $\begin{array}{c}\text { Total } \\
\text { protein }\end{array}$ & $\begin{array}{l}\text { Clotting } \\
\text { activity }\end{array}$ & Yield & $\begin{array}{r}\text { Purifi- } \\
\text { cation }\end{array}$ \\
\hline & $m l$ & $m g$ & $U$ & $\%$ & - fold \\
Plasma & 2,000 & $15.3 \times 10^{4}$ & $1.7 \times 10^{3}$ & 100 & 1 \\
$\begin{array}{l}\text { Al(OH) } \\
\text { DEAE- }\end{array}$ & 203 & $7.3 \times 10^{2}$ & $1.66 \times 10^{3}$ & 97.2 & 204 \\
$\begin{array}{l}\text { Sephadex } \\
\text { DE-52 }\end{array}$ & 90 & $1.1 \times 10^{2}$ & $1.6 \times 10^{3}$ & 94.2 & 1,301 \\
$\begin{array}{l}\text { Heparin- } \\
\quad \text { agarose }\end{array}$ & 180 & 10.3 & $1.0 \times 10^{3}$ & 59.0 & 8,769 \\
\hline
\end{tabular}

dicates that the zymogen form of both molecules is composed of a single polypeptide chain (Fig. 1). To show that the bands on SDS gels were indeed Factor IX, the purified normal Factor IX and Factor IX $_{\mathrm{CH}}$ were electrophoresed on .non-denatured polyacrylamide gels. Two gels for each product were used. One gel was stained with Coomassie Blue (Bio-Rad Laboratories, Richmond, Calif.) to identify the position of the protein band while the other gel was sliced into 1-2 $\mathrm{mm}$ lengths and eluted with buffered citrated saline as shown in Figs. 2 and 3. As can be seen in Fig. 2, normal Factor IX clotting activity was eluted in the same position as the protein band. In Fig. 3 both clotting and immunologic assays were used to detect Factor $\mathrm{IX}_{\mathrm{CH}}$. On immunoelectrophoresis and immunodif-

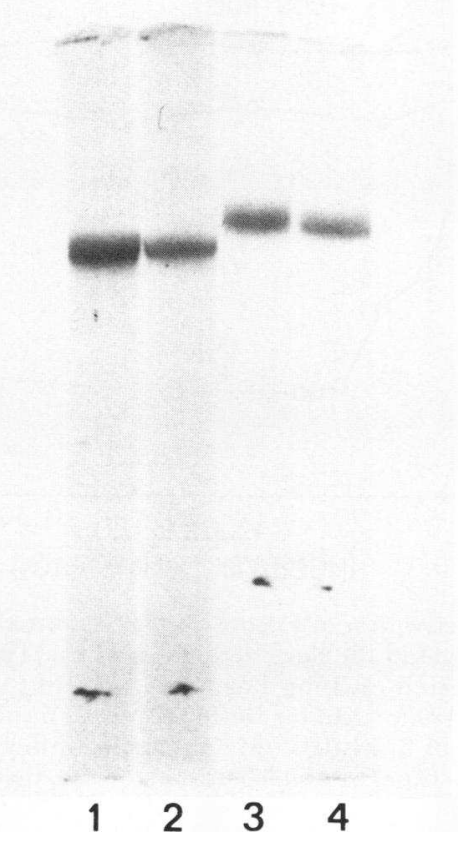

FIGURE 1 SDS gel electrophoresis of: (1) nonreduced Factor IX $_{\mathrm{CH}}$; (2) nonreduced normal Factor IX; (3) reduced Factor $\mathrm{IX}_{\mathrm{CH}} ;(4)$ reduced normal Factor IX.
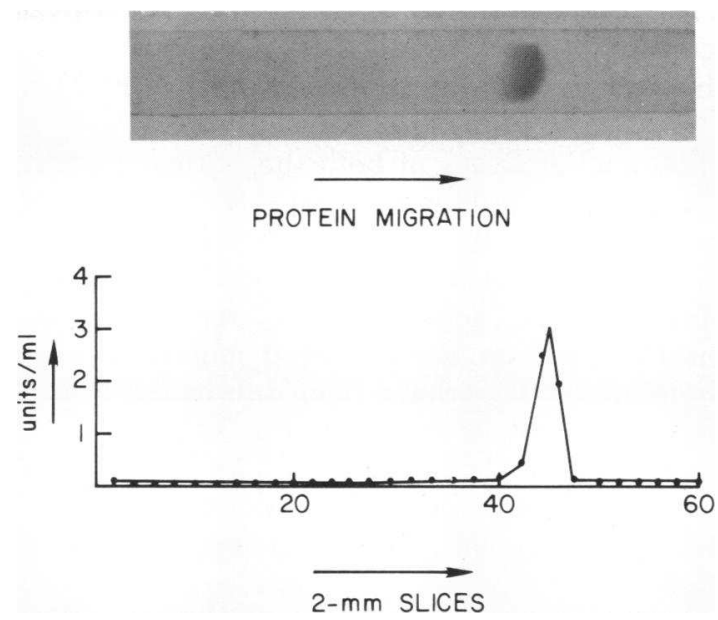

Figure 2 Disc gel electrophoresis of normal human Factor IX. $15 \mu \mathrm{g}$ of purified normal human Factor IX was electrophoresed in $7.5 \%$ polyacrylamide as shown on the top panel. Protein was identified by staining with Coomassie Blue. The migration was toward the anode. A duplicate gel was sliced into $2-\mathrm{mm}$ segments, as shown in the lower panel, and each segment was crushed and incubated with $0.2 \mathrm{ml} 0.15 \mathrm{M} \mathrm{NaCl}$ in $0.05 \mathrm{M}$ imidazole- $\mathrm{HCl}$ buffer $(\mathrm{pH} 6.0)$ at $4^{\circ} \mathrm{C}$ overnight. The sample was centrifuged and the supernate assayed for Factor IX.

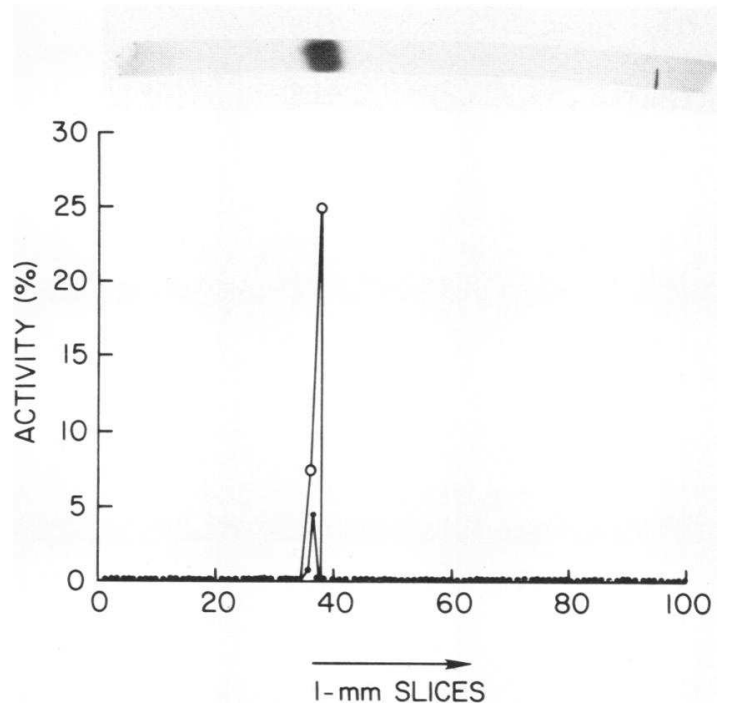

Figure 3 Disc gel electrophoresis of Factor $\mathrm{IX}_{\mathrm{CH}} \cdot 15 \mu \mathrm{g}$ of purified Factor IX $\mathrm{C}_{\mathrm{CH}}$ was electrophoresed on $7.5 \%$ polyacrylamide as shown in the top panel. The protein was identified by staining with Coomassie Blue. The migration was toward the anode. A duplicate gel was sliced into $1-\mathrm{mm}$ segments and each segment was crushed and incubated with $0.1 \mathrm{ml} 0.15$ $\mathrm{M} \mathrm{NaCl}$ in $0.05 \mathrm{M}$ imidazole buffer (pH 6.0) at $4^{\circ} \mathrm{C}$ overnight. The Factor IX clotting activity was assayed with the onestage method and the antigenic activity was assayed by the techniques described in Methods: (O) antigenic activity; (O) clotting activity. 
fusion, purified normal Factor IX and $\mathrm{IX}_{\mathrm{CH}}$ were not recognized by antibodies to whole human serum, albumin, prothrombin, and Factor $\mathrm{X}$ but were reactive with anti-Factor IX antibodies.

Amino acid analyses of both the normal Factor IX and Factor $\mathrm{IX}_{\mathrm{CH}}$ are shown in Table III. The amino acid compositions of both Factor IX proteins are similar. Both normal Factor IX and Factor IX $_{\mathrm{CH}}$ contain 10 $\gamma$-carboxyglutamic acid residues per molecule of Factor IX based on our observed molecular weight for the peptide. They have been subtracted from the glutamic acid content as reported in Table III.

The $\mathrm{NH}_{2}$-terminal amino acid of both the normal and abnormal molecule is tyrosine, as determined by both automatic and manual methods on several determinations.

The carbohydrate content of normal Factor IX and $\mathrm{IX}_{\mathrm{CH}}$ is also shown in Table III. The carbohydrate content of each protein is nearly identical except for a

TABLE III

Amino Acid and Carbohydrate Compositions of Normal Factor IX and Factor IX $X_{C H}$

\begin{tabular}{|c|c|c|}
\hline Components & Factor IX & Factor $\mathrm{IX}_{\mathrm{CH}}$ \\
\hline Amino acid & \multicolumn{2}{|c|}{$\begin{array}{l}\text { no. of } \\
\text { residues }\end{array}$} \\
\hline Asp & 51.9 & 50.4 \\
\hline Thr & 32.8 & 30.9 \\
\hline Ser & 32.6 & 33.7 \\
\hline Glu & 53.8 & 56.1 \\
\hline Pro & 17.6 & 20.4 \\
\hline Gly & 43.3 & 43.1 \\
\hline Ala & 28.6 & 30.1 \\
\hline Cys/2 & 24.0 & 26.5 \\
\hline Val & 32.1 & 31.5 \\
\hline Met & 6.3 & 3.9 \\
\hline Ile & 19.9 & 17.9 \\
\hline Leu & 32.2 & 32.2 \\
\hline Tyr & 18.3 & 18.1 \\
\hline Phe & 23.0 & 19.8 \\
\hline Lys & 29.7 & 29.1 \\
\hline $\mathrm{His}$ & 10.0 & 10.7 \\
\hline Arg & 22.1 & 20.5 \\
\hline Trp & 10.0 & 10.1 \\
\hline Gla* & 9.8 & 10.2 \\
\hline Total residues & 498.0 & 495.2 \\
\hline Mol wt & 56,600 & 56,600 \\
\hline Carbohydrates & & \\
\hline Galactose & 1.81 & 1.93 \\
\hline Mannose & 1.72 & 1.65 \\
\hline Glucose & 0.31 & 0.41 \\
\hline Fucose & 0.39 & 0.51 \\
\hline Hexosamines & 7.30 & 7.00 \\
\hline Sialic Acid & 6.40 & 7.60 \\
\hline Total & 17.93 & 19.10 \\
\hline
\end{tabular}

* $\gamma$-Carboxyglutamic acid. slightly higher sialic acid content of Factor $\mathrm{IX}_{\mathrm{CH}}$, but this is within the limits of experimental error.

The results of activation of both normal Factor IX and Factor $\mathrm{IX}_{\mathrm{CH}}$ are shown in Fig. 4. In this experiment, when normal Factor IX is activated by Factor $\mathrm{XIa}$ and $\mathrm{Ca}^{2+}$, the clotting times are progressively shortened. When purified Factor $\mathrm{IX}_{\mathbf{C H}}$ is activated by Factor XI and $\mathrm{Ca}^{2+}$ under the same conditions, very little shortening of the unactivated partial thromboplastin time is observed. If Factor XIa, Factor IX, or $\mathrm{Ca}^{2+}$ is omitted from the incubation mixture as a control, there is again very little shortening of the clotting time.

When the activation of normal Factor IX is followed by SDS gel electrophoresis, as shown in Fig. 5, the 70,000 -mol wt band is converted to a lower molecular weight component (estimated mol wt 50,000) within $30 \mathrm{~min}$. When Factor $\mathrm{IX}_{\mathrm{CH}}$ is activated under the same conditions, no change in molecular weight is observed. Even after incubation for $20 \mathrm{~h}$, only very little lower molecular weight component was formed. These findings were consistent on several determinations.

The extinction coefficients $\left(\mathrm{E}_{280}^{1 \%} \mathrm{~nm}\right)$ were similar, 11.8 for Factor IX and 12.5 for Factor $\mathrm{IX}_{\mathrm{CH}}$.

\section{DISCUSSION}

An abnormal Factor IX molecule obtained from a patient with mild hemophilia $B$ has been isolated and

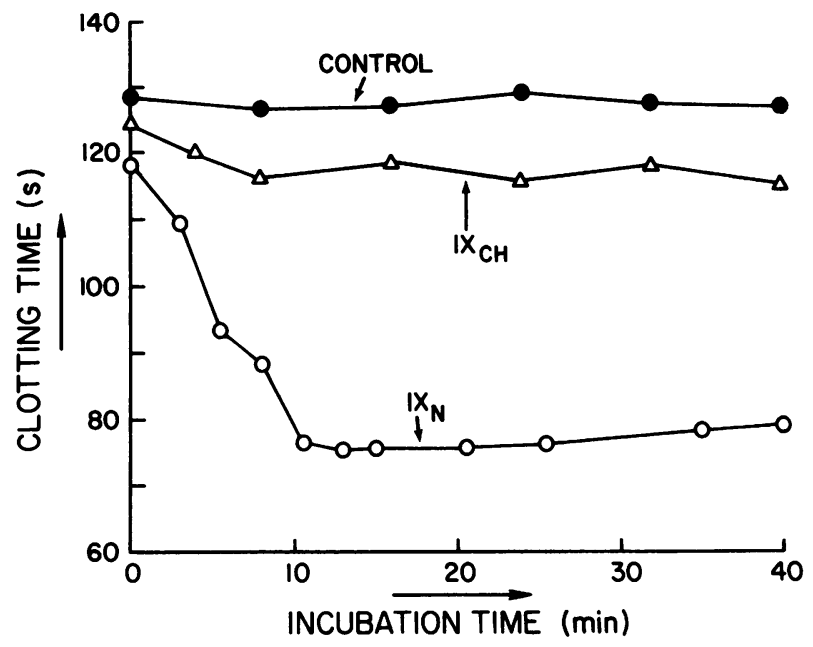

FIGURE 4 Activation of Factor $\mathrm{IX}_{\mathrm{CH}}$ and normal human Factor IX by activated human Factor XI and Ca. The incubation mixture consisted of $3 \mathrm{mg}$ Factor IX protein (or buffer control); $100 \mu \mathrm{g}$ Factor XIa (or buffer control); $5 \mathrm{mM} \mathrm{CaCl}_{2}$ in a final volume of $3 \mathrm{ml}(0.05 \mathrm{M}$ imidazole buffer, $\mathrm{pH} 6.0)$. At the indicated time intervals, $0.1 \mathrm{ml}$ of the incubation mixture was diluted with imidazole buffer (1:200 for Factor IX and 1:20 for Factor $\left.\mathrm{IX}_{\mathrm{CH}}\right)$ and was added to $0.1 \mathrm{ml}$ unactivated Factor IX-deficient substrate. Clotting was achieved by the addition of $0.2 \mathrm{ml}$ of a $1: 1$ mixture of $32 \mathrm{mM} \mathrm{CaCl}_{2}$ and $10 \%$ Thrombofax in normal saline. 


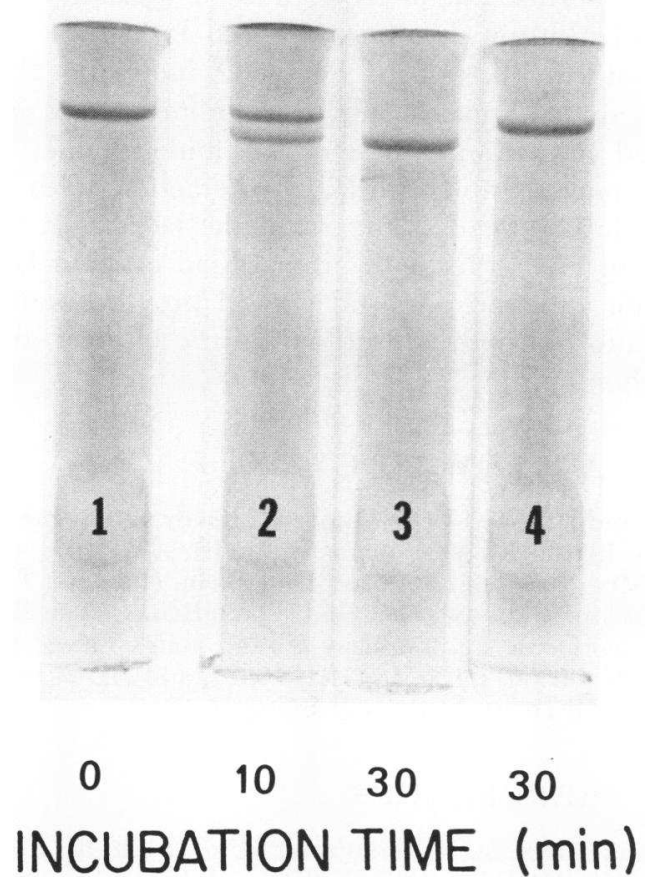

Figure 5 Activation of Factor $\mathrm{IX}_{\mathrm{CH}}$ and normal human Factor IX by activated human Factor XI and $\mathrm{Ca}$. The activation conditions were the same as those described in Fig. 4 except that at the indicated time interval, an aliquot of the incubation mixture which contained $\cong 15 \mu \mathrm{g}$ protein was subjected to SDS gel electrophoresis. Gels $1-3$ show normal Factor IX which was converted to a lower molecular weight component. Gel 4 shows Factor $\mathrm{IX}_{\mathrm{CH}}$ which showed no change in molecular weight.

characterized. The patient's plasma contains $5 \%$ Factor IX clotting activity but $100 \%$ Factor IX antigen as determined by radioimmunoassay and by antibody neutralization experiments as previously described. This variant Factor IX (Factor IX $\mathrm{X}_{\mathrm{CH}}$ ) was first described by Aronson (23) who noted that addition of $\mathrm{SrCl}_{2}$ to the patient's plasma did not result in activation of the patient's Factor IX, while addition of $\mathrm{SrCl}_{2}$ to normal plasma caused rapid activation of normal Factor IX. After activation promoted by $\mathrm{SrCl}_{2}$, the apparent molecular weight of the patient's Factor IX did not change, while that of normal Factor IX, as estimated on a Sephadex column (Pharmacia Fine Chemicals, Inc.), had a smaller molecular weight (23). However, Aronson used a plasma preparation, not a purified Factor IX.

We have purified Factor IX $_{C H} 18,000$-fold. The product is homogeneous by several criteria. In the purification procedure, the DE-52 ion exchange and the heparinagarose affinity chromatography are critical. In the former, the flow rate must be maintained at least at 60 $\mathrm{ml} / \mathrm{h}$. On heparin-agarose chromatography, calcium ions were used to enhance the binding of both normal Factor IX and Factor $\mathrm{IX}_{\mathrm{CH}}$ to the column. In the presence of $2.5 \mathrm{mM} \mathrm{CaCl}_{2}$, prothrombin does not bind to the column and can be collected in relatively pure form after the sample application. The column is washed extensively with imidazole buffer, which contains $0.25 \mathrm{M} \mathrm{NaCl}$ and $2.5 \mathrm{mM} \mathrm{CaCl}_{2}$, to remove Factor $\mathrm{X}$ and prothrombin remaining in the column. Factor $\mathrm{IX}_{\mathrm{CH}}$ can then be eluted with $0.4 \mathrm{M} \mathrm{NaCl}$ in the same buffer.

Factor $\mathrm{IX}_{\mathbf{C H}}$ resembles normal human Factor IX in several respects. Although several other values of molecular weight for normal human Factor IX have been reported $(2-6,8)$ including one as low as 57,000 as determined by sedimentation equilibrium (8), higher molecular weights are found with the Laemmli SDS gel method (35). Nevertheless, it is apparent that both Factor IX moleculars have a similar molecular weight. In addition, both normal Factor IX and Factor IX $_{\mathrm{CH}}$ have tyrosine as the $\mathrm{NH}_{2}$-terminal amino acid. Amino acid analyses of both proteins are very similar. Compared to analyses for normal human Factor IX published by other investigators $(2,3,6,8)$, by normalizing molecular weights to 50,000 , our analyses were found to be in good agreement with some reports in terms of most of the individual amino acid $(3,8)$ as well as the total residues (8). This type of analysis, however, obviously does not exclude a single amino acid substitution in Factor $\mathrm{IX}_{\mathrm{CH}}$. Furthermore, the carbohydrate content of the normal and abnormal molecules is similar and is in agreement with that reported by others for the normal molecule $(3,6,8)$. Moreover, Factor $\operatorname{IX}_{\mathbf{C H}}$ contains the same number of $\gamma$-carboxyglutamic acid residues as normal Factor IX. Thus, there is no evidence that the abnormality in Factor $\mathrm{IX}_{\mathrm{CH}}$ is the result of defective $\gamma$-carboxylation of the molecule during postribosomal modification in the hepatic parenchymal cells.

Of particular interest are the studies on the activation of Factor $\mathrm{IX}_{\mathrm{CH}}$. Activation of this abnormal Factor IX by Factor XIa and $\mathrm{Ca}^{2+}$, when followed by both coagulation assays and SDS gel electrophoreses, strongly suggests that the major abnormality in Factor IX $_{C_{H}}$ is defective activation. These findings are in agreement with those reported by Aronson (23), except that activation of the purified protein is even slower than in a plasma system. Thus, it is possible that the major defect of Factor $\mathrm{IX}_{\mathrm{CH}}$ is delayed activation under physiological conditions. Factor $\mathrm{IX}_{\mathrm{CH}}$ may be the result of a single amino acid substitution governed by gene(s) on the $\mathrm{X}$ chromosome. Such a substitution could retard the cleavage of bonds that result in the two-chain Factor IXa molecule. Prolonged incubation of Factor $\operatorname{IX}_{\mathrm{CH}_{\mathrm{H}}}$ with Factor XIa and $\mathrm{Ca}^{2+}$ for up to $20 \mathrm{~h}$ does result in the formation of a lower molecular weight component, but this process is very slow and most of the Factor $\mathrm{IX}_{\mathrm{CH}_{\mathrm{H}}}$ remains in the zymogen form. Activated Factor $\mathbf{I X}_{\mathrm{CH}}$ has not yet been isolated in amounts sufficient to com- 
pare specific activity of Factor $\mathrm{IXa}_{\mathrm{CH}}$ with that of normal Factor IXa. Fujikawa et al. (10) and Lindquist et al. (48) have shown, with purified bovine Factor IX, that an Arg-Ala bond is selectively cleaved by Factor XIa resulting in an inactive intermediate; a second proteolytic step cleaves an Arg-Val bond, releases a carbohydrate-rich activation peptide, and results in activated Factor IX. Whether the amino acid substitution in Factor $\mathrm{IX}_{\mathrm{CH}}$ is close to sites of cleavage by Factor XIa and $\mathrm{Ca}^{2+}$, or whether the substitution is remote and exerts its effect through tertiary conformational changes that hinder the proteolytic action of Factor XIa is not yet elucidated.

While it seems clear that Factor $\mathrm{IX}_{\mathrm{CH}}$ is not activated normally, it is difficult to determine whether this is the only defect. If Factor $\mathrm{IX}_{\mathrm{CH}}$ can be activated by substances such as Russell's viper venom or kallikrein, it would be possible to study the interaction of Factor $\mathrm{IXa}_{\mathrm{CH}}$ with calcium, lipid, and Factors VIII and X. These studies are currently in progress in our laboratory.

It could be postulated that the patient with Factor $\mathrm{IX}_{\mathrm{CH}}$ is synthesizing both a normal protein (that is contributing the 5\% coagulant activity) and a nonfunctioning protein that retains antigenic activity but not clotting activity. This explanation seems unlikely on a genetic basis because hemophilia B is inherited as an $\mathrm{X}$-linked recessive characteristic and it would be unlikely to have a gene coding for normal Factor IX and another for abnormal Factor IX. Moreover, in the activation experiment with clotting assays, one would expect $5 \%$ normal Factor IX to activate normally which was not the case. The Factor IX protein purified from the affected patient is probably composed entirely of a Factor IX protein that does not function normally in coagulation reactions.

Other abnormal Factor IX molecules almost certainly exist as initially postulated by Fantl et al. (49), Roberts et al. (12), and Hougie and Twomey (50). The latter authors described a hemophilia $B_{M}$ kindred which was shown to be $\mathrm{CRM}^{+}$by Brown et al. (16) and which has recently been purified and characterized by $\emptyset$ sterud et al. (51). Factor $\mathbf{I X}_{\mathrm{BM}}$ differs from Factor $\mathbf{I X}_{\mathrm{CH}}$ in that the former is associated with a prolonged ox-brain prothrombin time and can be activated by Factor XIa in the presence of $\mathrm{Ca}^{2+}(51)$. Furthermore, it should be noted that Factor $\mathrm{IX}_{\mathrm{CH}}$ is different from the Factor IX abnormality in hemophilia B Leyden (52). The Factor IX level in hemophilia B Leyden increases as the patient gets older. This is not the case with the patient with Factor $\mathrm{IX}_{\mathrm{CH}}$ who has been followed since childhood. Factor $\mathrm{IX}_{\mathrm{CH}}$ is also different from CRM $^{\mathrm{R}}$ and $\mathrm{CRM}^{-}$kindred previously reported by us (53). Furthermore, Factor VII levels are normal in the patient with Factor $\mathrm{IX}_{\mathrm{CH}}$ who is thus different from the Factor IX variants reported by Kasper et al. (14) and Girolami et al. (15).

Studies of abnormal Factor IX molecules should help in resolving some of the structure function relationships of normal Factor IX because the putative amino acid substitutions in the abnormal forms may affect different functions of the Factor IX molecule. For example, some abnormal Factor IX proteins may exhibit delayed activation by Factor XIa and calcium, while others may exhibit defective interaction with other blood clotting factors. The molecular basis of the interaction of Factor IX with other blood clotting factors, calcium, and phospholipid should provide better insight into the pathophysiology of the clinical disease state, hemophilia B.

\section{ACKNOWLEDGMENTS}

We are indebted to Doctors Richard Hiskey and Roger Lundblad for helpful suggestions and criticisms. We also wish to thank Mrs. K. Su Chung, Miss Patti Bean, and Mrs. Thelma Duncan for expert technical and secretarial assistance.

This work was supported by United States Public Health grants HL 06350, HL 07149, HL 16633, and HL 20161 from the National Heart, Lung, and Blood Institute.

\section{REFERENCES}

1. Fujikawa, K., A. R. Thompson, M. E. Legaz, R. G. Meyer, and E. W. Davie. 1973. Isolation and characterization of bovine factor IX (Christmas factor). Biochemistry. 12: 4938-4945.

2. $\emptyset$ sterud, B., and R. Flengsrud. 1975. Purification and some characteristics of the coagulation factor IX from human plasma. Biochem. J. 145: 469-474.

3. Andersson, L-O., H. Borg, and M. Miller-Andersson. 1975. Purification and characterization of human factor IX. Thromb. Res. 7: 451-459.

4. Rosenberg, J. S., P. W. McKenna, and R. D. Rosenberg, 1975. Inhibition of human factor IX $_{a}$ by human antithrombin. J. Biol. Chem. 250: 8883-8888.

5. Thompson, A. R. 1977. Factor IX antigen by radioimmunoassay. Abnormal factor IX protein in patients on warfarin therapy and with hemophilia B. J. Clin. Invest. 59: 900-910.

6. Suomela, H. 1976. Human coagulation factor IX: isolation and characterization. Eur. J. Biochem. 71: 145-154.

7. Chung, K. S., H. M. Reisner, and H. R. Roberts. 1976. Purification and characterization of human blood clotting factor IX. Circulation. 54(II): 118. (Abstr.)

8. Di Scipio, R. G., M. A. Hermodson, S. G. Yates, and E. W. Davie. 1977. A comparison of human prothrombin, factor IX (Christmas factor), factor X (Stuart factor), and protein S. Biochemistry. 16: 698-706.

9. Kingdon, H. S., and R. L. Lundblad. 1975. Biochemistry of factor IX. In Handbook of Hemophilia. K. M. Brinkhous and H. C. Hemker, editors. Excerpta Medica, Amsterdam, The Netherlands. 103-118.

10. Fujikawa, K., M. E. Legaz, H. Kato, and E. W. Davie. 1974. The mechanism of activation of bovine factor IX (Christmas factor) by bovine factor $\mathrm{XI}_{\mathrm{a}}$ (activated plasma thromboplastin antecedent). Biochemistry. 13: 45084516.

11. Titani, K., D. L. Enfield, K. Katayama, L. H. Ericsson, K. Fujikawa, K. A. Walsh, and H. Neurath. 1977. Primary structure of bovine factor IX. Thromb. Haemostasis. 38: 116. (Abstr.)

12. Roberts, H. R., J. E. Grizzle, W. D. McLester, and G. D. Penick. 1968. Genetic vai ants of hemophilia B: Detec- 
tion by means of a specific PTC inhibitor. J. Clin. Invest. 47: 360-365.

13. Фrstavik, K. H., B. Фsterud, H. Prydz, and K. Berg. 1975. Electroimmunoassay of factor IX in hemophilia B. Thromb. Res. 7: 373-382.

14. Kasper, C. K., B. Østerud, J. Y. Minami, W. Shonick, and S. I. Rapaport. 1977. Hemophilia B: Characterization of genetic variants and detection of carriers. Blood. 50: 351-366.

15. Girolami, A., A. Sticchi, A. Burul, and R. Dal Bo Zanon. 1977. An immunological investigation of hemophilia $B$ with a tentative classification of the disease into five variants. Vox. Sang. 32: 230-238.

16. Brown, P. E., C. Hougie, and H. R. Roberts. 1970. The genetic heterogeneity of hemophilia B. N. Engl. J. Med. 283: 61-64.

17. Meyer, D., E. Bidwell, and M. J. Larrieu. 1972. Cross reacting material in genetic variants of haemophilia B. J. Clin. Pathol. (Lond.) 25: 433-436.

18. Pfueller, S., J. B. Somer, and P. A. Castaldi. 1969. Haemophilia B due to an abnormal factor IX. Coagulation. 2: 213-219.

19. Elödi, S., and E. Puskas. 1972. Variants of hemophilia B. Thromb. Diath. Haemorrh. 28: 489-495.

20. McLester, W. D., H. R. Roberts, and R. H. Wagner. 1965. Use of immunosorbent technique in the study of a PTC inhibitor: A new method for the investigation of blood coagulation. 1965. J. Lab. Clin. Med. 66: 682-687.

21. Roberts, H. R., G. P. Gross, W. P. Webster, I. I. Dejanov, and G. D. Penick. 1966. Acquired inhibitors of plasma factor IX: A study of their induction, properties and neutralization. Am. J. Med. Sci. 251: 43-50.

22. Neal, W. R., D. T. Tayloe, Jr., A. I. Cederbaum, and H. R Roberts. 1973. Detection of genetic variants of hemophilia B with an immunosorbent technique. Br. J. Haematol. 25: $63-68$.

23. Aronson, D. L. 1975. Recent advances in hemophilia. Ann. N. Y. Acad. Sci. 240: 92-94.

24. Chung, K. S., J. C. Goldsmith, and H. R. Roberts. 1976. Purification and characterization of factor IX Chapel Hill. Blood. 48: 974. (Abstr.)

25. Lowry, O. H., N. J. Rosebrough, A. L. Farr, and R. J. Randall. 1951. Protein measurement with the Folin phenol reagent. J. Biol. Chem. 193: 265-275.

26. Langdell, R. D., R. H. Wagner, and K. M. Brinkhous. 1953. Effect of antihemophilic factor on one-stage clotting tests: a presumptive test for hemophilia and a simple onestage anti-hemophilic factor assay procedure.J. Lab. Clin. Med. 41: 637-647.

27. Barrow, E. M., W. Bullock, and J. B. Graham. 1960. A study of the carrier state for plasma thromboplastin component (PTC, Christmas factor) deficiency, utilizing a new assay procedure. J. Lab. Clin. Med. 55: 936-945.

28. Hougie, C., E. M. Barrow, and J. B. Graham. 1957. Stuart clotting defect. I. Segregation of an hereditary hemorrhagic state from the heterogeneous group heretofore called "Stable Factor" (SPCA, proconvertin, Factor VII) deficiency. J. Clin. Invest. 36: 485-496.

29. Smith, H. P., E. D. Warner, and K. M. Brinkhous. 1937. Prothrombin deficiency and the bleeding tendency in liver injury (Chloroform intoxication). J. Exp. Med. 66: 801811.

30. Horowitz, H. I., W. P. Wilcox, and M. M. Fujimoto. 1963. Assay of plasma thromboplastin anticedent (PTA) with artificially depleted normal plasma. Blood. 22: 35-43.

31. Kingdon, H. S., E. W. Davie, and O. D. Ratnoff. 1964. The reaction between activated plasma thromboplastin antecedent and diisopropylphosphofluoridate. Biochemistry. 3: 166-173.
32. Reisner, H. M., K. S. Chung, and H. R. Roberts. 1976. A radioimmunoassay for factor IX utilizing human inhibitors. American Society of Hematology Annual Session. Grune \& Stratton, Inc., New York. 397. (Abstr.)

33. Porath, J. 1974. General methods and coupling procedures. Methods Enzymol. 34: 13-30.

34. Cuatrecasas, P. 1970. Protein purification by affinity chromatography. J. Biol. Chem. 245: 3059-3065.

35. Laemmli, U. K. 1970. Cleavage of structural proteins during the assembly of the head of bacteriophage T4. Nature (Lond.). 227: 680-685.

36. Lundblad, R. L. and H. S. Kingdon. 1974. Biochemistry of the interaction of bovine factors XIa and IX. Thromb. Diath. Haemorrh. 57: 315-333.

37. Edman, P., and G. Begg. 1967. A protein sequenator. Eur. J. Biochem. 1: 80-91.

38. Woods, K. R., and K. T. Wang. 1967. Separation of dansylamino acids by polyamide layer chromatography. Biochim. Biophys. Acta. 133: 369-370.

39. Spackman, D. H., W. H. Stein, and S. Moore. 1958. Automatic recording apparatus for use in the chromatography of amino acids. Anal. Chem. 30: 1190-1206.

40. Hauschka, P. V., J. B. Lian, and P. M. Gallop. 1975. Direct identification of the calcium-binding amino acid, $\gamma$-carboxyglutamate in mineralized tissue. Proc. Natl. Acad. Sci. U. S. A. 72: 3925-3929.

41. Moore, S. 1963. On the determination of cystine as cysteic acid. J: Biol. Chem. 238: 235-237.

42. Benize, W. L., and K. Schmid. 1957. Determination of tyrosine and tryptophan in proteins. Anal. Chem. 29: 1193-1196.

43. Niedermeier, W. 1971. Gas chromatography of neutral and amino sugars in glycoproteins. Anal. Chem. 40: 465475.

44. Laine, R., H. Söderlund, and O. Renkonen. 1973. Chemical composition of Semliki Forest virus. Intervirology. 1: $110-118$.

45. Dubois, M., K. A. Gilles, J. K. Hamilton, P. A. Rebers, and F. Smith. 1956. Colorimetric method for determination of sugars and related substances. Anal. Chem. 28: 350-356.

46. Gardell, S. 1957. Determination of hexosamines. Methods Biochem. Anal. 6: 289-317.

47. Warren, L. 1959. The thiobarbituric acid assay of sialic acid. J. Biol. Chem. 234: 1971-1975.

48. Lindquist, P. A., K. Fujikawa, and E. W. Davie. 1978. Activation of bovine factor IX (Christmas factor) by factor XIa (activated plasma thromboplastin antecedent) and a protease from Russell's viper venom. J. Biol. Chem. 253: 1902-1909.

49. Fantl, P., R. J. Sawers, and A. G. Marr. 1956. Investigation of a haemorrhagic disease due to beta-prothromboplastin deficiency complicated by a specific inhibitor of thromboplastin formation. Australas. Ann. Med. 5: 163-176.

50. Hougie, C., and J. J. Twomey. 1967. Haemophilia $B_{M}$ : A new type of factor IX deficiency. Lancet. I: 698-700.

51. Đsterud, B., K. Lavine, C. K. Kasper, and S. I. Rapaport. 1977. Isolation and properties of the abnormal factor IX molecule of hemophilia $\mathrm{B}_{\mathrm{M}}$. Thromb. Haemostasis. 38: 51. (Abstr.)

52. Veltkamp, J. J., J. Meilof, H. G. Remmelts, D. van der Vlerk, and E. A. Loeliger. 1970. Another genetic variant of haemophilia B: Haemophilia B Leyden. Scand. J. Haematol. 7: 82-90.

53. Roberts, H. R., and A. I. Cederbaum. 1975. Molecular variants of factor IX. In Handbook of Hemophilia. K. M. Brinkhous and H. C. Hemker, editors. Excerpta Medica, Amsterdam, The Netherlands. 237-246. 